\title{
Lifestyle Factors and Internet Addiction among School Children
}

\author{
Abdulbari Bener ${ }^{1,2 *}$, Huda S. Al-Mahdi ${ }^{3}$ and Dinesh Bhugra ${ }^{4}$ \\ ${ }^{1}$ Department of Biostatistics \& Medical Informatics, Cerrahpaşa Faculty of Medicine, Istanbul University, Istanbul, Turkey \\ ${ }^{2}$ Department of Evidence for Population Health Unit, School of Epidemiology and Health Sciences, University of Manchester, Manchester, UK \\ ${ }^{3}$ Department of Ophthalmology, Rumailah and Hamad General Hospitals, Hamad Medical Corporation, Qatar \\ ${ }^{4}$ HSPRD, Section of Cultural Psychiatry, Institute of Psychiatry, King's College London, UK
}

\begin{abstract}
Aim: The current study aimed to determine the association between Internet Addition [IA] and fatigue, sleep disturbance, depression, and life style factors among school children.

Subjects \& Methods: A cross-sectional survey based on Public and Private intermediate and secondary School students in Doha- Qatar. A total of 1624 students 12-18 years of age were approached using multistage stratified random sampling and 1,188 students (73.3\%) gave consent during October 2011 to December 2012. Data collection was based on a structure questionnaire including socio-demographic details, lifestyle and dietary habits Internet Addiction Test (IAT), Fatigue Scale, Epworth Sleepiness Scale [ESS] and Beck Depression Inventory (BDI) test. Univariate and multiple logistic regression analysis were performed.

Results: The overall prevalence of IA among school children was $19.8 \%$. The proportion of IA was significantly more among males $(56.4 \%)$ as compare to females $(43.6 \% ; \mathrm{p}=0.035)$, school performance $(\mathrm{p}<0.001)$ and family income $(\mathrm{p}=0.032)$. Those with IA had significantly less number of sleep hours ( $6.16 \pm 0.80$ vs. $6.58 \pm 1.29$; $\mathrm{p}<0.001)$ as compared to normal. Those with IA had significantly high number of hours internet use $(3.82 \pm 1.64$ vs. $3.03 \pm 1.64 ; \mathrm{p}<0.001)$ as compared to normal. A significantly larger proportion of IA than normal subjects reported having headaches $(\mathrm{p}=0.010)$, double vision $(\mathrm{p}=0.037)$, eye hurt $(\mathrm{p}=0.021)$, eye tired $(\mathrm{p}=0.005)$, dizziness $(34.4 \%$ vs. $27.3 \% ; \mathrm{p}=0.002)$, and hearing problem $(\mathrm{p}=0.048)$. A significantly larger proportion of students with IA most frequently gratifying site (19.9\% vs. $11.6 \%$; $<<0.001)$, browsed games ( $38.6 \%$ vs. $29.9 \%$; $=0.010)$, chat sites $(29.7 \%$ vs. $22 \%$; $p=0.013)$, email ( $54.2 \%$ vs. $63.1 \% ; \mathrm{p}=0.36)$, and research $(61.0 \%$ vs. $69.2 \% ; \mathrm{p}=0.017)$. Those with IA had significantly high number fatigue disorders, because significantly high number of hours internet use $(\mathrm{p}<0.001)$ as compared to normal.

Conclusion: The current study confirmed the of evidence linking problematic internet use with negative fatigue, greater numbers of symptoms, anxiety, sleeping disturbances, depressive and lifestyle risk factors, among vulnerable young children.
\end{abstract}

\section{Introduction}

Recent advances in internet network and smartphones have made it possible for anyone to enjoy internet use and games regardless of time and physical location. The internet misuse among children's has become a widespread global major public health [1-5].

The phenomenon of internet addiction was first described in a number of papers by both Griffiths [1,2] and Young [3]. The topic immediately gained more general attention and has since become a highly researched popular area. Unfortunately, certain internet sites, especially those involving online socializing, can affect behaviour and lead to pathological thinking [2-6]. Problematic Internet use (PIU) is defined in the fifth edition of the Diagnostic and Statistical Manual of Mental Disorders (DSM-V) [7]. Several studies have established that children and adolescents in particular are becoming addicted to playing internet games, in much the same way as adults become addicted to alcohol or drug or gambling [1-3, 8-9]. It has been observed that the case for IA is very evident; with increasingly sophisticated infrastructures developing throughout the world, it will certainly emerge as a more prominent issue. People, who have psychological and emotional issues such as depression, loneliness, social anxiety, impulsivity, and distraction, easily get addicted to technology like the internet [1-3]. In addition, the place where internet accesses, the duration of internet use, peer relationships and parenting are relevant. Internet as a tool addition is also associated with the physical and psychological problems such as dry eyes, carpal tunnel syndrome, repetitive motion injuries, wrist, neck, back and shoulder pain, migraine headaches and numbness and pain in the thumb, index and middle fingers [6].

Several studies have documented adverse effects of IA among school children such as irregular dietary habits [10-11], physical inactivity, lack of adequate sleep [3,12-13] and increased depression $[5,6,14]$ loneliness, and social anxiety [15-16]. However, very a few have investigated the association of excessive internet use with fatigue, sleeping disorders, and psychiatric problems in this region. The aim of present study was to determine the relationship between IA and fatigue, sleep disturbance, depression, and life style factors among school children.

\section{Methods}

This is a cross-sectional study included students aged between 12 18 years, studying in the Intermediate and secondary levels in Qatar. ${ }^{*}$ Corresponding Author: Prof. Abdulbari Bener, Advisor to WHO, Professor of Public Health, Department of Biostatistics \& Medical Informatics, Cerrahpaşa Faculty of Medicine, Istanbul University, 34098 Cerrahpasa-Istanbul,Turkey, Tel: +90-212-414 3041; E-mail: abdulbari.bener@istanbul.edu.tr

Citation: Bener A, Al-Mahdi HS, Bhugra D (2016) Lifestyle Factors and Internet Addiction among School Children. Int J Community Fam Med 1: 118. doi: https:// doi.org/10.15344/2456-3498/2016/118

Copyright: (c) 2016 Bener et al. This is an open-access article distributed under the terms of the Creative Commons Attribution License, which permits unrestricted use, distribution, and reproduction in any medium, provided the original author and source are credited. 
Citation: Bener A, Al-Mahdi HS, Bhugra D (2016) Lifestyle Factors and Internet Addiction among School Children. Int J Community Fam Med 1: 118. doi: https://doi.org/10.15344/2456-3498/2016/118

Page 2 of 6

The study has been based on the Problematic Internet use (PIU) as described in the fifth edition of the Diagnostic and Statistical Manual of Mental Disorders (DSM-V) [7]. Twenty schools were selected among which ten were boys' and ten were girls' schools, located in 5 districts and schematic sampling procedure presented in Figure 1 . We have computed the sample size based on $50 \%$ prevalence of students might have access to internet services and addict, assuming $3.2 \%$ bound on error estimation, and taking $99 \%$ confidence level, the required minimum sample size for this study was $\mathrm{N}=1,624$.

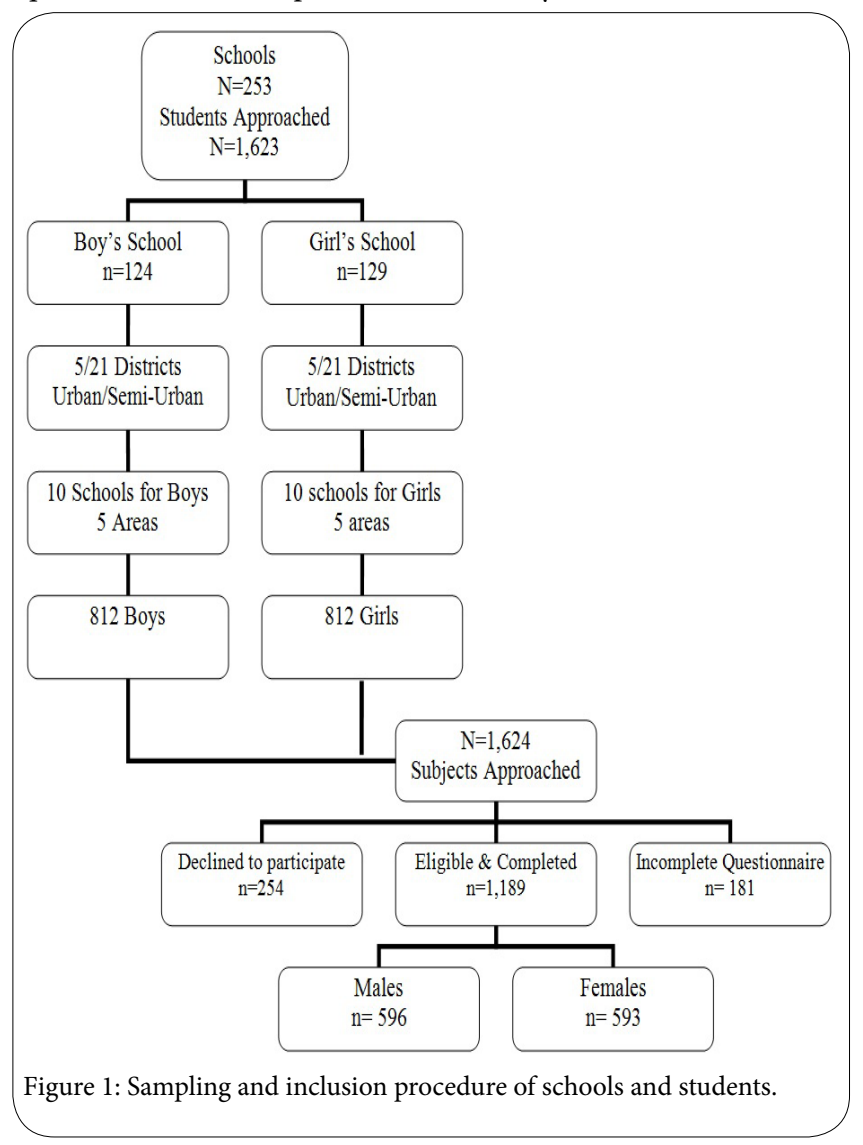

\section{Assessment}

The questionnaire based on five sections: The socio-demographic details of the student; the lifestyle habits, extra curricular activities and hobbies including physical activity and exercise; dietary habits the internet use and included validated Young's Internet Addiction Test (IAT) [1-3,18] and finally, the fifth part consisted of the Beck Depression Inventory (BDI) [17], fatigue [18] and Epworth Sleepiness Scale [21]. Data collection took place from October 2011 to December 2012. A total of 1,624 students were approached and 1,188 students consented to participate in the study giving a response rate of $73.7 \%$. Content validity, face validity and reliability of the questionnaire were tested using 79 students. These tests demonstrated a high level of validity and reliability (Cranach's Alpha $=0.85)$.

\section{The Beck Depression Inventory (BDI)}

The Beck Depression Inventory (BDI) is a long-standing, widelyused, self-evaluation depression scale with 21 questions composed, each with four possible responses [17]. Items 1 to 13 assess symptoms that are psychological in nature, while items 14 to 21 assess more physical symptoms. A score of 21 or above represents depression.

\section{Fatigue measure and design of scale}

The potential health risks fatigue has been associated with excessive internet usage [19] The Fatigue scale is composed of 14 statements that describe fatigue symptoms commonly seen in subjects [20]. A list of 14 questions were generated by various experts in the field to reflect physical and mental fatigue. The Likert Scale baed on composition such as : $1=$ better than usual , $2=$ no more than usual, $3=$ =worse than usual and $4=$ much worse than usual 4 . The results revealed that the optimum cut-off is $75 \%$ with the area under the ROC curve. Internal consistency in the present study was explored for fatigue scale, Cronbach's alpha calculated for physical fatigue items (1-8) was 0.85 ; and for mental fatigue items (9-14) items was 0.82 respectively.

\section{The Epworth Sleepiness Scale}

The Epworth Sleepiness Scale [ESS] is a useful tool to identify symptoms of daytime sleepiness and it was introduced by Johns [21]. The validated ESS is based eight-item questionnaire that assesses the severity of daytime sleepiness in various situations. The numbers selected for the eight items in the ESS score from are range 0 to 24 . The score ranging from 1 to 10 is normal and score from 11 to 24 is considered to be abnormal. Cronbach's alpha for the ESS was also obtained 0.88 .

\section{Statistical methods}

Data was analyzed using SPSS version 22. Sum of scores were calculated for IAT, BDI, Fatigue and ESS. Student-t test was used to determine the significance of differences between mean values of two continuous variables. The Chi-square and Fisher's exact tests (two-tailed) were performed to test for differences in proportions of categorical variables between two or more groups. Unpaired student's $t$ test was employed for comparison of two means. A multivariate linear regression model with stepwise elimination was constructed to identify the determinants of internet addiction for the potential confounders. The level $\mathrm{p}<0.05$ was considered as the cut-off value for significance.

\section{Results}

The overall prevalence of IA among school children was $19.8 \%$. Table 1 shows socio-demographic characteristics of the participants with IA and normal students. The proportion of IA was significantly more among males $(56.4 \%)$ as compare to females $(43.6 \%$; $=0.035)$, school performance $(\mathrm{p}<0.001)$ and family income $(\mathrm{p}=0.032)$.

Table 2 shows the lifestyle habits, diet and co-morbid factors of the studied students. Those with IA had significantly less number of sleep hours $(6.16 \pm 0.80$ vs. $6.58 \pm 1.29 ; \mathrm{p}<0.001)$ as compared to normal. Those with IA had significantly high number of hours internet use $(3.82 \pm 1.64$ vs. $3.03 \pm 1.64 ; \mathrm{p}<0.001)$ as compared to normal. A significantly larger proportion of IA than normal subjects reported having headaches $(\mathrm{p}=0.010)$, double vision $(\mathrm{p}=0.037)$, eye hurt $(\mathrm{p}=0.021)$, eye tired $(\mathrm{p}=0.005)$, dizziness $(34.4 \%$ vs. $27.3 \% ; \mathrm{p}=0.002)$, and hearing problem $(\mathrm{p}=0.048)$.

Table 3 gives comparison of fatigue disorders according to IA and normal students. Those with IA had significantly high number fatigue disorders, because significantly high number of hours internet use $(\mathrm{p}<0.001)$ as compared to normal. 
Citation: Bener A, Al-Mahdi HS, Bhugra D (2016) Lifestyle Factors and Internet Addiction among School Children. Int J Community Fam Med 1: 118. doi: https://doi.org/10.15344/2456-3498/2016/118

Page 3 of 6

\begin{tabular}{|c|c|c|c|c|}
\hline & Variable & IA & Normal & ${ }^{*}$ p-value \\
\hline & & $\mathrm{N}=236$ & $\mathrm{~N}=953$ & \\
\hline \multicolumn{5}{|l|}{ Nationality } \\
\hline & Qatari & $168(712)$ & 676(70.9) & 0.339 \\
\hline & Non-Qatari & $68(28.8)$ & $277(29.1)$ & \\
\hline \multicolumn{5}{|l|}{ Sex } \\
\hline & Male & $133(56.4)$ & $463(48.6)$ & 0.035 \\
\hline & Female & $103(43.6)$ & $490(51.4)$ & \\
\hline \multicolumn{5}{|l|}{ Age in Years } \\
\hline & $<15$ years & $96(40.7)$ & $459(48.2)$ & 0.041 \\
\hline & $>15$ years & $140(59.3)$ & $494(51.8)$ & \\
\hline \multicolumn{5}{|l|}{ Level of Education } \\
\hline & Intermediate & $143(60.6)$ & $578(60.8)$ & 0.763 \\
\hline & Secondary & $93(39.4)$ & $374(39.2)$ & \\
\hline \multicolumn{5}{|c|}{ Rank of Student in School Exam } \\
\hline & Very Good & $65(27.5)$ & $247(25.9)$ & 0.001 \\
\hline & Good & $77(32.6)$ & $400(42.0)$ & \\
\hline & Average & $77(32.6)$ & $282(29.6)$ & \\
\hline & Poor & $17(7.2)$ & $34(2.5)$ & \\
\hline \multicolumn{5}{|l|}{ Father's Education } \\
\hline & $\begin{array}{l}\text { Illiterate (no } \\
\text { formal schooling) }\end{array}$ & $9(5.5)$ & $40(4.2)$ & 0.616 \\
\hline & Primary & $17(13.0)$ & 98(10.3) & \\
\hline & Intermediate & $40(20.9)$ & $157(16.5)$ & \\
\hline & Secondary & $70(28.1)$ & $290(30.4)$ & \\
\hline & University & $100(32.4)$ & $368(38 . .6)$ & \\
\hline \multicolumn{5}{|l|}{ Father's Occupation } \\
\hline & $\begin{array}{l}\text { Not Working / } \\
\text { retired }\end{array}$ & $15(6.4)$ & $54(5.7)$ & 0.835 \\
\hline & $\begin{array}{l}\text { Sedentary/ } \\
\text { Professional }\end{array}$ & $87(36.9)$ & $372(39.0)$ & \\
\hline & Manual/Clerk & $18(7.6)$ & $89(9.3)$ & \\
\hline & Business man & $64(27.1)$ & $24(25.8)$ & \\
\hline & $\begin{array}{l}\text { Government } \\
\text { Officer }\end{array}$ & $52(22.0)$ & $192(20.1)$ & \\
\hline \multicolumn{5}{|l|}{ Mother's Education } \\
\hline & Illiterate & $32(13.6)$ & $152(15.9)$ & 0.070 \\
\hline & Primary & $31(13.1)$ & $183(19.2)$ & \\
\hline & Intermediate & $59(25.0)$ & $214(22.5)$ & \\
\hline & Secondary & $72(30.5)$ & $226(23.7)$ & \\
\hline & University & $42(17.8)$ & $178(18.7)$ & \\
\hline \multicolumn{5}{|c|}{ Mother's Occupation } \\
\hline & House wife & $88(35.6)$ & $334(35.0)$ & 0.576 \\
\hline & $\begin{array}{l}\text { Sedentary/ } \\
\text { Professional }\end{array}$ & $48(20.8)$ & $235(24.7)$ & \\
\hline & Manual/Clerk & $52(22.9)$ & $190(20.6)$ & \\
\hline & Business Woman & $48(20.8)$ & $188(19.7)$ & \\
\hline \multicolumn{5}{|l|}{ Family Income } \\
\hline & Low & $161(25.9)$ & $323(33.9)$ & 0.032 \\
\hline & Medium & $102(43.2)$ & $396(41.6)$ & \\
\hline & High & $73(30.9)$ & $234(24.6)$ & \\
\hline \multicolumn{5}{|c|}{$\begin{array}{l}\text { Table 1: Socio-demographics characteristic among Internet Addict and } \\
\text { normal students }(\mathrm{N}=1,189) \text {. } \\
\text { IA= Internet Addiction, Problematic internet use, } \\
\text { Normal = None Addiction or Non-problematic internet use }\end{array}$} \\
\hline
\end{tabular}

\begin{tabular}{|c|c|c|c|}
\hline Variables & $\begin{array}{l}\text { IA } \\
\mathrm{N}=\mathbf{2 3 6}\end{array}$ & $\begin{array}{l}\text { Normal } \\
\mathrm{N}=953\end{array}$ & $\begin{array}{l}\text { p-value * } \\
\text { Significance }\end{array}$ \\
\hline Age $($ Mean \pm SD $)$ & $15.16 \pm 2.06$ & $14.88 \pm 2.10$ & 0.064 \\
\hline $\begin{array}{l}\text { Number of Bed Rooms } \\
\text { at your House }\end{array}$ & $5.88 \pm 2.69$ & $5.90 \pm 2.83$ & 0.672 \\
\hline $\begin{array}{l}\text { Number of people are } \\
\text { living at Home }\end{array}$ & $5.84 \pm 1.97$ & $5.74 \pm 1.87$ & 0.350 \\
\hline Hours internet use & $3.82 \pm 1.64$ & $3.003 \pm 1.67$ & 0.001 \\
\hline Sleeping no of hours & $6.16 \pm 0.80$ & $6.32 \pm 1.24$ & 0.001 \\
\hline $\begin{array}{l}\text { Medical-Co-morbid } \\
\text { Factors }^{\star *}\end{array}$ & n (\%) & n (\%) & \\
\hline Headaches & 93(39.4) & 292(30.6) & 0.010 \\
\hline Blurred Vision & $52(22.0)$ & $200(21.0)$ & 0.724 \\
\hline Double Vision & $29(12.3)$ & $76(8.0)$ & 0.037 \\
\hline Eyes Hurt & $54(22.9)$ & $157(16.5$ & 0.021 \\
\hline Eye Tire & $57(24.2)$ & $155(16.3)$ & 0.005 \\
\hline Dizziness & $66(28.0)$ & $185(19.6)$ & 0.004 \\
\hline $\begin{array}{l}\text { Any Problem with } \\
\text { Hearing }\end{array}$ & $60(25.4)$ & $187(19.8)$ & 0.048 \\
\hline \multicolumn{4}{|c|}{ The Epworth Sleepiness Scale } \\
\hline Normal & $56(23.7)$ & $262(27.5)$ & \\
\hline Mild & $50(21.2)$ & $258(27.1)$ & 0.030 \\
\hline Moderate & $48(20.3)$ & $186(19.5)$ & \\
\hline Severe & $82(34.7)$ & $247(25.9)$ & \\
\hline \multicolumn{4}{|l|}{ Physical activities } \\
\hline Sport activities & $66(28.1)$ & $351(36.8)$ & 0.017 \\
\hline Physical activity & $77(32.6)$ & 938(39.9) & 0.040 \\
\hline \multicolumn{4}{|c|}{ Dieting information and Frequency of eating fast food ${ }^{\star}$} \\
\hline Daily & $30(12.7)$ & $81(8.5)$ & 0.026 \\
\hline Weekly & $58(24.6)$ & $188(19.7)$ & \\
\hline Monthly & $68(28.8)$ & $351(36.8)$ & \\
\hline Occasionally & $80(33.9)$ & $333(34.9)$ & \\
\hline \multicolumn{4}{|c|}{$\begin{array}{l}\text { Table } 2 \text { : The characteritics of life style, dietary and co-morbid factors } \\
\text { among Internet Addict and normal students }(\mathrm{N}=1,189) \text {. } \\
{ }^{*} \text { Two sided p values based on student } t \text { test } \\
{ }^{* *} \text { Not adding to } 100 \%\end{array}$} \\
\hline
\end{tabular}

Table 4 presents comparison of different internet activities among internet addicted and normal groups. A significantly larger proportion of students with IA most frequently gratifying site $(19.9 \%$ vs. $11.6 \%$; $\mathrm{p}<0.001)$, browsed games $(38.6 \%$ vs. $29.9 \%$; $\mathrm{p}=0.010)$, chat sites $(29.7 \%$ vs. $22 \%$; $\mathrm{p}=0.013)$, email $(54.2 \%$ vs. $63.1 \%$; $\mathrm{p}=0.36)$, and research $(61.0 \%$ vs. $69.2 \% ; \mathrm{p}=0.017)$.

Table 5 shows the multiple linear regression analysis to determine the potential predictors as risk factors for internet addiction. The data revealed that the duration of internet use, BDI depression; fatigue physical symptoms, EES sleeping, games, headache, fatigue mental symptom, dizziness, eye tired and hearing problem were significantly associated and leading predictors for internet addiction.

\section{Discussion}

The current survey presents clearly that PIU is associated with depressive symptoms, sleeping disturbance, co-morbid factors and poor lifestyle habits. It is worth to note that Qatar has very high prevalence of PIU (19.8\%) when compared to Greece (8\%) [15], and Taiwan (13.8\%) [22] in Australia (10.2\%) [23] and in Tunisia (18\%) [24]. Although it is difficult to compare the exact prevalence of IA due to the lack of a shared criterion, this study highlights the importance of consistently using a similar validated tool so that to help in comparison across different population. 
Citation: Bener A, Al-Mahdi HS, Bhugra D (2016) Lifestyle Factors and Internet Addiction among School Children. Int J Community Fam Med 1: 118. doi: https://doi.org/10.15344/2456-3498/2016/118

Page 4 of 6

\begin{tabular}{|c|c|c|c|}
\hline 14 - Item fatigue scale & $\begin{array}{l}\mathrm{IA} \\
\mathrm{N}=236\end{array}$ & $\begin{array}{l}\text { Normal } \\
\text { Students } \\
\mathrm{N}=953\end{array}$ & $\mathrm{p}$ Value \\
\hline \multicolumn{4}{|l|}{ Physical symptoms } \\
\hline $\begin{array}{l}\text { 1. Do you have problem with } \\
\text { tiredness? }\end{array}$ & $3.01 \pm 1.60$ & $2.17 \pm 1.65$ & 0.001 \\
\hline 2. Do you need to rest more? & $2.85 \pm 1.22$ & $2.35 \pm 1.11$ & 0.001 \\
\hline $\begin{array}{l}\text { 3. Do you feel sleepy or } \\
\text { drowsy? }\end{array}$ & $2.92 \pm 1.05$ & $2.22 \pm 1.13$ & 0.001 \\
\hline $\begin{array}{l}4 \text { Do you have problems } \\
\text { starting things? }\end{array}$ & $2.82 \pm 1.05$ & $2.44 \pm 1.24$ & 0.001 \\
\hline $\begin{array}{l}\text { 5. Do you start things without } \\
\text { difficulty but get weak as you } \\
\text { go on? }\end{array}$ & $2.70 \pm 1.10$ & $2.48 \pm 1.18$ & 0.001 \\
\hline 6. Are you lacking in energy? & $3.16 \pm 1.00$ & $2.54 \pm 1.22$ & 0.001 \\
\hline $\begin{array}{l}\text { 7. Do you have less strength in } \\
\text { your muscle? }\end{array}$ & $2.87 \pm 1.08$ & $2.36 \pm 1.21$ & 0.001 \\
\hline 8. Do you feel weak? & $2.96 \pm 1.07$ & $2.65 \pm 1.24$ & 0.001 \\
\hline \multicolumn{4}{|l|}{ Mental symptoms } \\
\hline $\begin{array}{l}\text { 9. Do you have difficulty } \\
\text { concentrating? }\end{array}$ & $2.68 \pm 1.14$ & $2.38 \pm 1.00$ & 0.001 \\
\hline $\begin{array}{l}\text { 10. Do you have problems } \\
\text { thinking clearly }\end{array}$ & $2.92 \pm 1.05$ & $2.50 \pm 1.16$ & 0.001 \\
\hline $\begin{array}{l}\text { 11. Do you make lips of the } \\
\text { tongue when speaking? }\end{array}$ & $2.70 \pm 1.19$ & $2.32 \pm 1.15$ & 0.001 \\
\hline $\begin{array}{l}\text { 12. Do you fin it more difficult } \\
\text { to find the correct word? }\end{array}$ & $2.60 \pm 1.26$ & $2.62 \pm 1.23$ & 0.785 \\
\hline 13. How is your memory? & $2.73 \pm 1.16$ & $2.36 \pm 1.15$ & 0.001 \\
\hline $\begin{array}{l}\text { 14. Have you lot interest in the } \\
\text { thing } s \text { you used to do }\end{array}$ & $2.73 \pm 1.16$ & $2.44 \pm 1.49$ & 0.001 \\
\hline
\end{tabular}

Table 3. The comparison of fatigue physical and mental symptoms according Internet Addiction and normal subjects $(\mathrm{N}=1,189)$.

\begin{tabular}{|c|c|c|c|}
\hline Variables & $\begin{array}{l}\text { IA } \\
\mathrm{N}=236\end{array}$ & $\begin{array}{l}\text { Normal } \\
N=953\end{array}$ & $\begin{array}{l}{ }^{*} \mathrm{p} \text {-value } \\
\text { significance }\end{array}$ \\
\hline IAT Score $($ Mean \pm SD $)$ & $73.50 \pm 4.41$ & $55.48 \pm 7.10$ & 0.001 \\
\hline BDI Score $($ Mean \pm SD $)$ & $27.25 \pm 6.80$ & $20.79 \pm 6.78$ & 0.001 \\
\hline $\begin{array}{l}\text { Fatigue physical } \\
\text { symptoms }\end{array}$ & $23.38 \pm 2.44$ & $19.23 \pm 3.13$ & 0.001 \\
\hline $\begin{array}{l}\text { Fatigue mental } \\
\text { symptoms }\end{array}$ & $16.19 \pm 2.88$ & $14.62 \pm 3.22$ & 0.001 \\
\hline $\begin{array}{l}\text { Epworth Sleepiness } \\
\text { Score }\end{array}$ & $13.58 \pm 4.82$ & $12.71 \pm 4.47$ & 0.013 \\
\hline Internet activities ${ }^{* *}$ & $\mathrm{n}(\%)$ & $\mathrm{n}(\%)$ & \\
\hline Gratifying Site & $47(19.9)$ & $111(11.6)$ & 0.001 \\
\hline Games & $91(38.6)$ & $285(29.9)$ & 0.010 \\
\hline Chat & $70(29.7)$ & $210(22.0)$ & 0.013 \\
\hline Face book & $47(19.9)$ & $181(16.9)$ & 0.274 \\
\hline Community & $30(12.7)$ & $125(13.1)$ & 0.869 \\
\hline email & $128(54.2)$ & $588(61.7)$ & 0.036 \\
\hline Research & $144(61.0)$ & $659(69.2)$ & 0.017 \\
\hline Gambling & $18(7.6)$ & $54(5.7)$ & 0.258 \\
\hline eBay shopping & $26(11.0)$ & $119(12.5)$ & 0.537 \\
\hline
\end{tabular}

Table 4. The means and standard deviations for internet problems (IAT), depression (BDI), fatigue, (HADS), sleep problems (EES) and internet activities according Internet Addict and normal students $(\mathrm{N}=1,189)$.

${ }^{*}$ Two sided $p$ values based on Chi square for categorical and student $t$ test for the quantitative variables.

${ }^{* *}$ Multiple option and multivariable choice, percentages do not add to $100 \%$.

\begin{tabular}{|l|l|l|l|l|l|}
\hline $\begin{array}{l}\text { Independent } \\
\text { Variables }\end{array}$ & $\mathrm{B}$ & $\begin{array}{l}\text { Standard } \\
\text { Error }\end{array}$ & Beta & $\begin{array}{l}\mathrm{t} \text { test } \\
\text { value }\end{array}$ & $\begin{array}{l}\text { p-value } \\
\text { significance }\end{array}$ \\
\hline $\begin{array}{l}\text { Internet use in } \\
\text { hours }\end{array}$ & -0.027 & 0.006 & -0.115 & -.4 .725 & $<0.001$ \\
\hline BDI Score & -0.015 & 0.001 & -0.277 & -.11 .323 & $<0.001$ \\
\hline $\begin{array}{l}\text { Fatigue } \\
\text { physical } \\
\text { symptoms }\end{array}$ & -0.040 & 0.003 & -0.352 & -.13 .899 & $<0.001$ \\
\hline $\begin{array}{l}\text { Epworth } \\
\text { Sleepiness } \\
\text { Score }\end{array}$ & -0.008 & 0.002 & -0.090 & -.3 .687 & $<0.001$ \\
\hline $\begin{array}{l}\text { Sleeping in } \\
\text { hours }\end{array}$ & 0.030 & 0.008 & 0.091 & 3.617 & $<0.001$ \\
\hline Games playing & 0.065 & 0.021 & 0.076 & 3.136 & 0.002 \\
\hline Headache & 0.071 & 0.024 & 0.085 & 2.958 & 0.003 \\
\hline $\begin{array}{l}\text { Fatigue mental } \\
\text { symptoms }\end{array}$ & -0.009 & 0.003 & -0.072 & -.2 .873 & 0.004 \\
\hline Dizziness & 0.070 & 0.024 & 0.071 & 2.884 & 0.004 \\
\hline Eye tired & 0.069 & 0.033 & 0.066 & 2.090 & 0.038 \\
\hline $\begin{array}{l}\text { Hearing } \\
\text { problem }\end{array}$ & 0.056 & 0.028 & 0.057 & 2.000 & 0.049 \\
\hline Tabe 5: & andivare & & & \\
\hline
\end{tabular}

Table 5: Multivariable stepwise regression analysis predictors for determinants of Internet Addiction affect $(\mathrm{N}=1,189)$.

The Korean study [8] reported that IA is associated with lack of sleep, fatigue symptoms such as physical and mental and frequent consumption of fast food. This is with current and previous reported studies [1].

The study at hand, builds on the small but increasing body of literature linking IA to depression. The findings of the present study have confirmed the findings of the three main studies which have found correlations between IA and depression, namely an American study by Young and Rogers [3] in a sample of adults $(\mathrm{N}=259)$; a Korean study $(\mathrm{N}=452)$ [14] among adolescents and a UK study [4] among adults between $16-51$ years in the UK $(\mathrm{N}=1319)$. In a similar fashion to the current study all of these previous studies used the Internet Addiction [19] to measure internet addiction and the Beck Depression Inventory (BDI) [17-18] to measure levels of depression, with the exception of the Korean study which used the Korean version of the Center for the Epidemiologic Study of Depression Scale (CED-S). The main weakness of the Korean study [14] was its small sample size; as for the UK study [5], its main weakness was its sampling technique of recruiting participants from online social networking sites, which may have resulted in a bias towards those who utilize such sites. The current study strengthened the findings relating IA to depression as it had a larger sample size and more rigorous sampling technique as consistent with the previous studies [9-14].

More recently a Chinese study $(\mathrm{N}=1041)$ [23] has found a causal link between IA and depression among adolescents. It was established that the risk of depression for those who used the Internet pathologically was about two and a half times more that of those who did not [23]. More recently, Tunisian study [24] reported that the prevalence of Internet Addiction was $18.05 \%$ and daily average time of Internet use was $4.5 \pm 2.84$ hour compared to 1.02 hours \pm 1.56 among normal internet student users $(\mathrm{P}=0.001)$. This is confirmative with the present and earlier study studies [4-5,10-11]. 
Citation: Bener A, Al-Mahdi HS, Bhugra D (2016) Lifestyle Factors and Internet Addiction among School Children. Int J Community Fam Med 1: 118. doi: https://doi.org/10.15344/2456-3498/2016/118

Page 5 of 6

The present study revealed that there was a correlation between time spent on the internet, and viewing gratifying sites, games, chat and facebook. This finding confirms what other global internet studies have documented [1-6, 22-26]. Essentially, these other studies have noted that adolescents have a tendency to spend prolonged time on the internet on gaming and socially interactive sites. In a Greek study [15] among adolescents $(n=897)$ it was found that the main aim of overall internet use was social interaction; moreover, it found that the internet access to play games via internet cafes was an important predictor for high users. Similar findings were found in a Taiwanese study among adolescents $(\mathrm{n}=1708)$ [22] and a Dutch study among adolescents $(n=4920)$ [25] which documented that online gaming and surfing with a social/entertainment motivation and gratification were positively correlated with IA. A possible explanation for the gaming addiction and social interactive sites was reported by Byun et al.[26] The main reasons behind were such as socializing functions, real-time interactions using email, discussion forums, chat rooms and online games [3]. The current study results showed similar pattern.

Present study revealed that misuse or abuse of internet is very frequent among school students. Several studies reported some prevention techniques for children, their families and health professionals [24, 27]. Internet use should modify since Internet becomes a gold mine of information and communication. Furthermore, the fact that some students are not aware of these harmful consequences on their health, time management, social life, finance and academic achievement currently and in the future. Unfortunately, lack of Internet education in school curricula is a deficiency and needs to fulfill.

The study had several limitations. The study based on cross-sectional study design. The questionnaire was self-reported for depression and sleeping disturbances. Fatigue also relied on participants' self-reported levels of subjective. Finally, the primary symptoms of addictive behavior are to hide the amount of time spent in game, gratifying sites and chatting activities. Despite those limitations, we think the sample size is adequate and the results provide more information of prevalence of IA and associated risk factors.

\section{Home messages}

This study revealed the impact of excessive internet use as burden on disability and health care of students. The primary health care and school health physicians, who are the centre point of health care services, have a critical role in identifying and treating Internet addicted victims with physical and mental symptoms.

\section{Highlight}

- This study showed that Internet and game were significantly associated with fatigue, sleeping, depressive disorder and anxiety disorders.

- Severity of depression in the Internet and Game Addiction group was higher than that in the normal group.

\section{Conclusion}

In conclusion, the current study confirmed and added to the growing body of evidence an association of depression, fatigue, anxiety, symptoms, smoking addiction with IA in children whereas age, sex, school performance, socio-economic status have association as known before. The study highlights adverse effects of IA on children development, as a result of lost interest in communication with people, inadequate dietary habits, poor social relationships, sleep disturbance, psychological symptoms such as fatigue, anxiety and depression, could be relevant to predict IA students.

\section{Acknowledgement}

The author would like to thank Hamad Medical Corporation (HMC RP\#11029/11) for their support and ethical approval. Finally, the author is very grateful to the Supreme Council for Education and Higher Education for their support and help in performing this study.

\section{Funding}

This work was generously supported and funded by the Qatar National Research Fund.

\section{Competing Interests}

The author(s) declare that they have no competing interests.

\section{Author Contributions}

$\mathrm{AB}$ organized study, collected data, performed statistical analysis and wrote the first draft of the article, and contributed to the interpretation of the data and writing the final draft of manuscript. $\mathrm{HA}$ and $\mathrm{DB}$ contributed to the interpretation of the data and writing the manuscript.

\section{References}

1. Király O, Griffiths MD, Urbán R, Farkas J, Kökönyei G, et al. (2014) Problematic internet use and problematic online gaming are not the same: Findings from a large nationally representative adolescent sample. Cyberpsychol Behav Soc Netw 17: 749-754.

2. Kuss DJ, Griffiths MD, Karila L, Billieux J (2014) Internet addiction: A systematic review of epidemiological research for the last decade. Current Pharmaceutical Design 20: 4026-4052.

3. Young KS, Rogers RC (1998) The relationship between depression and Internet addiction. CyberPsychology and Behavior 1: 25-28.

4. Bener A, Bhugra D (2013) Lifestyle and depressive risk factors associated with problematic internet use in adolescents in an Arabian Gulf culture. $J$ Addict Med 7: 236-242.

5. Morrison CM, Gore H (2010) The Relationship between Excessive Internet Use and Depression: A Questionnaire-Based Study of 1,319 Young People and Adults. Psychopathology 43: 121-126.

6. Park S, Hong KE, Park EJ, Ha KS, Yoo HJ (2013) The association between problematic internet use and depression, suicidal ideation and bipolar disorder symptoms in Korean adolescents. Aust N Z J Psychiatry 47: 153159.

7. American Psychiatric Association (2013) Diagnostic and Statistical Manual of Mental Disorders-Text Revision. 5th edition. DC, USA: American Psychiatric Association

8. Lam LT, Peng ZW, Mai JC, Jing J (2009) Factors associated with Internet addiction among adolescents. Cyberpsychol Behav 12: 551-555

9. Kim Y, Park JY, Kim SB, Jung IK, Lim YS, et al. (2010) The effects of Internet addiction on the lifestyle and dietary behavior of Korean adolescents. Nutr Res Pract 4: 51-57.

10. Bener A, Al-Mahdi HS, Ali Al, Al-Nufal M, Vachhani PJ, et al. (2011) Obesity and low vision as a result of excessive Internet use and television viewing. Int J Food Sci Nutr 62: 60-62. 
Citation: Bener A, Al-Mahdi HS, Bhugra D (2016) Lifestyle Factors and Internet Addiction among School Children. Int J Community Fam Med 1: 118. doi: https://doi.org/10.15344/2456-3498/2016/118

Page 6 of 6

11. Bener A, Al-Mahdi HS, Vachhani PJ, Al-Nufal M, Ali Al (2010) Do excessive internet use, television viewing and poor lifestyle habits affect low vision in school children? J Child Health Care 14: 375-385.

12. Choi K, Son H, Park M, Han J, Kim K, et al. (2009) Internet overuse and excessive daytime sleepiness in adolescents. Psychiatry Clin Neurosci 63: 455-462.

13. Reed P, Vile R, Osborne LA, Romano M, Truzoli R (2015) Problematic Internet Usage and Immune Function. PLoS One 10: e0134538.

14. Ha JH, Kim SY, Bae SC, Bae S, Kim H, et al. (2007) Depression and Internet addiction in adolescents. Psychopathology 40: 424-430

15. Siomos KE, Dafouli ED, Braimiotis DA, Mouzas OD, Angelopoulos NV (2008) Internet addiction among Greek adolescent students. Cyberpsycho Behav 11: 653-657.

16. Caplan SE (2007) Relations among loneliness, social anxiety, and problematic Internet use. Cyberpsychol Behav 10: 234-242.

17. Beck AT, Steer RA, Garbin GM (1988) Psychometric properties of the Beck Depression Inventory: Twenty-five years of evaluation. Clinical Psych Review 8: 77-100.

18. Beard KW (2005) Internet addiction: A review of current assessment techniques and potential assessment questions. Cyberpsychology Behavior 8: 7-14

19. Dol KS (2016) Fatigue and pain related to internet usage among university students. J Phys Ther Sci 28: 1233-1237.

20. Chalder T, Berelowitz G, Pawlikowska T, Watts L, Wessely S, et al. (1993) Development of a fatigue scale. J Psychosom Res 37: 147-153

21. John MW (2000) Sensitivity and specificity of the multiple sleep latency test (MSLT), the maintenance of the wakefulness test and the Epworth Sleepiness Scale: Failure of the MSLT as a gold standard. J Sleep Res 9: 5-11.

22. Yang SC, Tung CJ (2007) Comparison of Internet addicts and non-addicts in Taiwanese high school. Comp Human Behavior 23: 79-96.

23. Lam LT, Peng ZW (2010) Effect of pathological use of the internet on adolescent mental health: a prospective study. Arch Pediatr Adolesc Med 164: 901-906.

24. Chérif L, Ayedi $\mathrm{H}$, Hadjkacem I, Khemekhem $\mathrm{K}$, Khemekhem $\mathrm{S}$, et al. (2015) [Problematic Internet use among teenagers in Sfax, Tunisia]. Encephale 41: 487-492.

25. van Rooij AJ1, Schoenmakers TM, van de Eijnden RJ, van de Mheen D (2010) Compulsive Internet use: the role of online gaming and other internet applications. J Adolesc Health 47: 51-57.

26. Byun Griffiths MD (1998) Internet addiction: Does it really exist? In: Gackenbach J, ed. Psychology and the internet: Intrapersonal, interpersonal, and transpersonal implications. New York: Academic Press, pp. 61-75

27. Bener A, Al-Mahdi HS (2012) Internet use and Television Viewing in Children and Its Association with Vision Loss: A Major Public Health Problem. J Public Health Africa 3: e16. 